\title{
MENINGKATKAN PENGGUNAAN MODA DARING MELALUI PEMBERDAYAAN MGMP SEKOLAH BERBASIS KOLABORASI
}

\author{
I NENGAH SURADNYA \\ SMP Negeri 1 Banjarangkan \\ Email : suradnyainengah5@gmail.com
}

\begin{abstract}
ABSTRAK
Penelitian Tindakan sekolah ini dilatarbelakangi masih rendahnya penguasaan teknologi guru-guru di SMPN 1 Banjarangkan khususnya pada masa pandemi, dimana pembelajarannya dilaksanakan dari rumah (BDR). Dari data yang diperoleh pada awal siklus $88,14 \%$ penggunaan satu moda daring, $8,47 \%$ penggunaan dengan dua moda daring dan 3,39\% tanpa menggunakan moda daring. PTS ini bertujuan untuk meningkatkan kemampuan guru-guru di SMPN 1 Banjarangkan dalam penggunaan moda daring melalui pemberdayaan MGMP sekolah berbasis kolaborasi. Penelitian dilaksanakan di SMPN 1 Banjarangkan dengan subyek penelitian guruguru SMPN 1 Banjarangkan yang berjumlah 67 orang yang tergabung dalam MGMP sekolah dan obyek penelitian adalah penggunaan moda daring dalam pembelajaran. Teknik pengumpulan data melalui observasi dan angket, dengan instrumen menggunakan lembar pengamatan dan angket dengan menggunakan google form. Data yang diperoleh dianalisis dengan statistik sederhana dengan menentukan prosentase penggunaan moda daring secara kuantitas dan diskriptif. Dari hasil analisis data pada siklus 1, 88,24\% guru menggunakan satu moda daring, 8,82\% menggunakan dua moda, dan 2,94\% dengan tiga moda daring. Pada siklus 2, 15,22\% guru-guru menggunakan satu moda daring, 60,87\% menggunakan dua moda daring, $21,73 \%$ menggunakan tiga moda daring dan $2,17 \%$ menggunakan tiga moda daring. Terdapat peningkatan penggunaan dua moda daring mengalami peningkatan $52,05 \%$, penggunaan tiga moda daring meningkat $18,79 \%$ dan penggunaan empat moda daring meningkat $2,17 \%$. Karena hasil penelitian telah memenuhi indikator keberhasilan yang ditetapkan yaitu minimal 50\% penggunaan moda daring dan minimal $20 \%$ guruguru menggunakan tiga moda daring maka dapat disimpulkan melalui pemberdayaan MGMP sekolah berbasis kolaborasi mampu meningkatkan penggunaan moda daring guru-guru di SMPN 1 Banjarangkan.
\end{abstract}

Kata kunci : Moda daring, MGMP Sekolah, Kolaborasi

\section{PENDAHULUAN}

Sejak ditetapkan penyebaran covid-19 sebagai wabah yang melanda dunia, WHO menjadikan sebagai keadaan darurat dan bencana yang harus diwaspadai. Di Indonesia kondisi ini melumpuhkan sendi-sendi kehidupan manusia, banyak tenaga kerja yang di rumahkan bahkan tidak sedikit tenaga kerja di PHK. Pengangguran terjadi dimana-mana, masyarakat kehilangan mata pencaharian, tidak sedikit kehilangan nyawa akibat terpapar virus corona. Menurut data per 3 Nopember 2020 dari satgas covid nasional jumlah masyarakat yang terpapar covid-19 berjumlah 433.836 orang, mengalami kesembuhan 364.417 orang dan meninggal dunia 14.540 
orang. Di Provinsi Bali data menunjukkan jumlah yang terpapar covid-19 11.906 orang, sembuh 10.847 orang dan meninggal dunia 392 orang. Sedangkan di Kabupaten Klungkung berdasarkan data satgas covid Kabupaten Klungkung per tanggal 5 Nopember 2020 terpapar covid-19 mencapai 872 orang, meninggal dunia 16 orang dengan jumlah sembuh mencapai 827 orang. Perubahan yang medadak dan tidak terduga-duga terjadi pada dunia Pendidikan, hal ini tercermin dari pergeseran pembelajaran tatap muka di kelas menjadi pembelajaran jarak jauh (PJJ) atau pembelajaran dari rumah (BDR). Menjadi tantangan pendidik untuk selalu memiliki ketrampilan dan kemampuan melaksanakan pembelajaran darurat. Hal ini sesuai dengan pendapat Koesoema (2018) yang mengatakan bahwa pendidik memperoleh pengayaan dan pengembangan profesinalisme agar memiliki bekal pengetahuan dan ketrampilan yang dibutuhkan untuk meningkatkan kualitas pembelajaran. Siswa dipaksa menyesuaikan kondisi yang berbeda, guru pun diwajibkan dengan pembelajaran berbasis digital atau teknologi. Ketidaksiapan dan ketidakbiasaan pembelajaran jarak jauh atau pembelajaran daring membawa dampak positif dan negatif. Dari data Komisioner KPAI, selasa, 12 Mei 2020 ternyata 79,9 persen mengalami stress, banyak beban, terkesan pembelajaran hanya penjejalan tugas. Kurang adanya pembimbingan, boros kouta, pembelajaran membosankan bahkan kurang bermakna. Di SMPN 1 Banjarangkan kemampuan penguasaan teknologi pada masa sebelum pandemi sesuai hasil cek list oleh tim IT masih tertumpu pada satu aplikasi. Dari 59 guru menguasai teknologi berbasis WA 88,14 \% menguasai dua aplikasi wa dan google form 8,47\% dan 3,39\% tanpa menggunakan aplikasi, sekolah belum memiliki Learning Management System (LMS). Pembelajaran jarak jauh melalui moda daring dapat dilakukan melalui tatap muka virtual seperti video conference, lewat aplikasi pesan dan dapat pula dilakukan melalui Learning Management System (LMS) seperti kelas maya rumah belajar, google classroom, zenius, ruang guru, melajah.id, moodle dan lain sebagainya (Kemendikbud, 2020:10). Teknologi memegang peranan yang sangat penting di abad 21 dalam meningkatkan kualitas guru dan peserta didik. Disamping itu teknologi merupakan syarat dalam persaingan di dunia kerja. Dengan teknologi pula proses pembelajaran akan lebih efektif, peserta didik akan dapat terlayani hak pendidikannya terutama di masa pandemic. Beberapa faktor penyebab kurangnya kemampuan penguasaan teknologi guru adalah dari pengamatan kepala sekolah rasa malas berlatih $14,93 \%$, malu bertanya 22,39\%, kurang bimbingan mencapai 6,27 dan sarana atau alat tenologi yang dimiliki guru-guru 7,46\%. Dari data tersebut masih kurangnya bimbingan yang diberikan kepada guru-guru dalam penguasaan penggunaan moda daring

Association for education communication and technology (2004) dalam (Dirjen Guru dan Tenaga Kependidikan, 2020) pada tahap I Bimtek Guru Belajar mengatakan bahwa mengintegrasikan teknologi dalam pendidikan merupakan upaya memfasilitasi pembelajaran dan meningkatkan kinerja dengan cara menciptakan, menggunakan/memanfaatkan, dan mengelola proses dan sumber-sumber teknologi yang tepat. Jelas, tujuan utamanya masih tetap untuk memfasilitasi pembelajaran (agar efektif, efisien dan menarik) serta meningkatkan kinerja. Hal di atas memberikan makna betapa penting peran penggunaan teknologi dalam pembelajaran 
jarak jauh moda daring dalam mengatasi permasalahan pembelajaran yang mencakup perencaanaan pembelajaran, pengeloaan pembelajaran dan pendekatan pembelajaran yang digunakan agar pembelajaran berjalan lebih efektif dan bermakna. Di masingmasing guru mata pelajaran memiliki kelompok kerja yang disebut dengan Musyawarah Guru Mata Pelajaran (MGMP) dari tingkat sekolah, kabupaten, provinsi bahkan tingkat nasional. MGMP di SMPN 1 Banjarangkan secara terjadwal mengadakan pertemuan dan memiliki peranan yang sangat penting. Kelompok kerja guru (KKG), musyawarah guru mata pelajaran (MGMP) atau musyawarah guru bimbingan dan konseling (MGBK) adalah wadah kegiatan guru kelas, guru mata pelajaran sejenis atau guru bimbingan dan konseling dalam usaha meningkatkan kemampuan profesional guru di bawah bimbingan guru inti dan bersifat mandiri (Permendiknas : 2010). Beberapa hal yang dapat dipetik dalam pemberdayaan MGMP sekolah saling berbagi (sharing) dalam penyusunan perangkat pembelajaran, bedah kurikulum, strategi pembelajaran, bimbingan terhadap siswa, keberanian tampil melalui presentasi, bimbingan teknologi dan memupuk rasa persaudaraan. Namun pada kenyataannya dari pemantauan kepala sekolah keberadaan MGMP di SMPN 1 Banjarangkan masih tertumpu pada kegiatan rutinitas yaitu pembuatan perangkat pembelajaran dan asesmen atau penilaian. Melihat dari kondisi tersebut perlulah langkah-langkah konkrit untuk menanggulangi permasalahn tersebut di atas. Salah-satu Langkah yang dapat dilakukan dalam meningkatkan kemampuan penggunaan moda daring guru-guru di SMPN 1 Banjarangkan adalah melalui pemberdayaan MGMP sekolah berbasis kolaborasi. Berdasarkan latar belakang masalah di atas rumusan masalah dalam penelitian ini adalah apakah melalui pemberdayaann MGMP berbasis kolaborasi dapat meningkatkan kemampuan penggunaan moda daring guru-guru di SMPN 1 Banjarangkan tahun ajaran 2020/2021? Langkah pemecahan masalah yang dilakukan dalam penelitian ini adalah dengan data awal yang telah diperoleh, kepala sekolah dengan tim pengembang kurikulum melakukan sosialisasi dengan warga sekolah dalam pengembangan kompetensi teknologi bagi warga sekolah. Dilanjutkan dengan penyusunan jadwal dan tim pedamping dalam usaha untuk pemberdayaan MGMP sekolah. Dalam kegiatan MGMP sekolah dirancang materi dan pedamping atau pembimbing secara berjenjang kepada guru-guru dalam proses bimbingan dan praktik penguasaan aplikasi pembelajaran daring yang meliputi wa, google form, google classroom, elearning dan aplikasi lainnya. Dalam proses bimbingan tidak berpusat pada satu mapel melainkan pada antar mapel dan dilakukan secara kolaborasi. Tujuan penelitian adalah untuk mengetahui kemampuan penggunaan moda daring guru-guru melalui pemberdayaan MGMP sekolah berbasis kolaborasi di SMPN 1 Banjarangkan tahun ajaran 2020/2021. Dari manfaat teoritis penelitian ini menambah wawasan dan pengetahuan peneliti. Lambat laun kemampuan teknologi siswa akan bertambah maupun berkembang. Kemampuan teknologi akan bertambah baik dari segi kualitas dan kuantitas. Penelitian ini akan memberikan dampak positif bagi sekolah dalam pengembangan budaya mutu sekolah berbasis teknologi terutama dalam kualitas proses pembelajaran. 


\section{METODE PENELITIAN}

Penelitian dilakukan di SMPN 1 Banjarangkan yang beralamat di Jalan Lettu Ida Bagus Puja Kecamatan Banjarangkan Kabupaten Klungkung Provinsi Bali. Jumlah tenaga pendidik 67 orang, tenaga kependidikan 18 orang, dengan jumlah siswa seluruhnya 787 orang. Jumlah mata pelajaran 12 mata pelajaran, sehingga memiliki 12 MGMP tingkat sekolah melalui SK Kepala Sekolah dengan susunan kepengurusan ketua MGMP dan anggota. Jenis penelitian adalah penelitian tindakan sekolah (PTS) dengan subjek penelitian adalah guru-guru mata pelajaran dan bimbingan di SMPN 1 Banjarangkan yang tergabung dalam wadah MGMP sekolah. Sedangkan objek penelitian adalah kemampuan pengunaan moda daring melalui pemberdayaan MGMP sekolah berbasis kolaborasi. Rancangan penelitian dilaksanakan dalam dua siklus dan tindakan dalam PTS yang terbagi dalam empat rangkaian tindakan yaitu (a) perencanaan, (b) pelaksanaan, (c) refleksi dan (d) observasi. Dalam pengumpulan data yang diperoleh pada penelitian ini menggunakan teknik observasi dan angket. Pengumpulan data dengan menggunakan lembar observasi dan lembar instrumen. Dimana guru-guru SMPN 1 Banjarangkan mengisi lembar angket melalui google form dan kepala sekolah melaksanakan pengamatan selama proses berlangsungnya MGMP sekolah dengan protocol Kesehatan dan aktifitas pembimbingan yang dilakukan oleh guru-guru kepada rekan-rekannya di MGMP sekolah melalui lembar pengamatan. Hasil data yang diperoleh dianalisis dengan statistik sederhana secara kuantitatif diskriftif dengan mencari prosentase kemampuan guru-guru SMPN 1 Banjarangkan dalam penguasaan penggunaan moda daring dalam pembelajaran, selanjutnya membandingkan hasil yang diperoleh. Dari hasil yang diperoleh dapat diberikan keterangan atau penarikan kesimpulan dalam bentuk deskripsi. Adapun jadwal penelitian dilaksanakan dari bulan Maret 2020 sampai bulan Oktober 2020. Pada penelitian tindakan sekolah ini, dikatakan berhasil apabila guru-guru di SMPN 1 Banjarangkan mampu menggunakan dua moda daring minimal $50 \%$ dan tiga moda daring minimal $20 \%$.

\section{HASIL DAN PEMBAHASAN}

\section{a. HASIL}

Berdasarkan pemetaan data awal $88,14 \%$ guru menguasai teknologi berbasis $w a$, menggunakan wa dan google form $8,47 \%$, dan tanpa pendekatan $3,39 \%$.

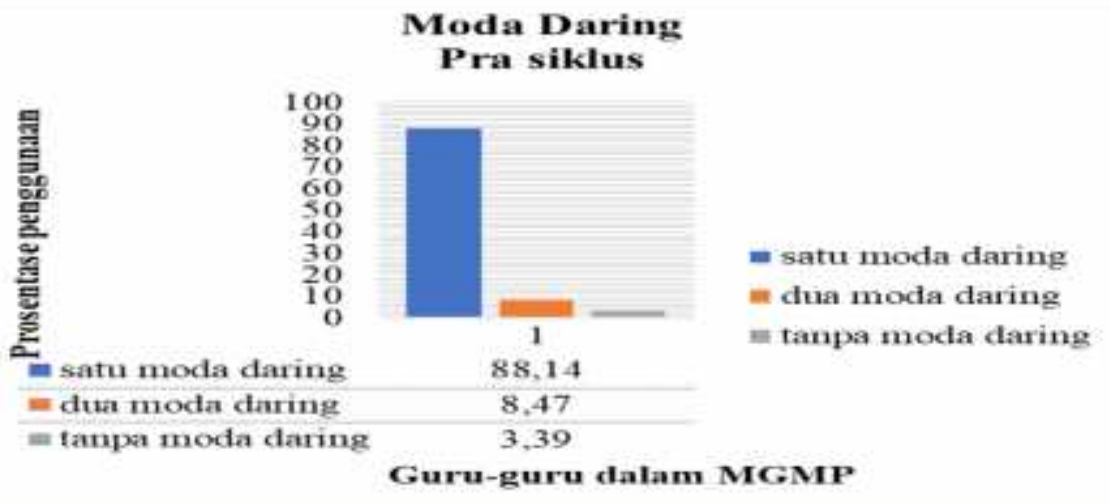

Gambar 1. Diagram Moda Daring Pra Siklus 
Data awal mencerminkan masih rendahnya kemampuan guru dalam penguasaan teknologi khususnya pendekatan pembelajaran daring hanya tertumpu pada penggunaan WAG. Penggunaan WAG memiliki nilai positif dan negatif. Nilai positifnya mudah digunakan, sudah sering dipakai dalam berkomunikasi, tidak ada petunjuk-petunjuk pekerjaan yang sulit. Namun kelemahan penggunaan WAG, file tugas dengan absen menumpuk sehingga sulit untuk dikontrol, antara siswa yang sudah mengabsen dengan belum, antara yang sudah mengumpul tugas dengan yang belum mengumpul tugas, sulit memeriksa tugas-tugas siswa, penglihatan jadi terganggu akibat banyak tugas yang dikumpul, apalagi jika dikirim kedalam WAG kelas. Adapun data yang diperoleh pada siklus 1, melalui WA 88,24\%, wa, google form 2,94\%, wa, e-learning $2,94 \%$, wa, google classroom 2,94\% dan yang tiga moda daring wa, google form, google classroom 2,94\%. Google Classroom sebagai salah-satu aplikasi moda daring di tengah pandemi dapat mengatasi keterbatasan ruang dan waktu sehingga guru lebih mudah melaksanakan evaluasi yang dilakukan siswa, pemantauan diskusi kelas berjalan lebih efektif, dapat juga mengulang materi agar dapat meningkatkan hasil belajar (https://metrojambi.com/read/2020/03/29/52180/metode-belajar-daringberbasis-it-google-classroom-di-tengah-pandemi-covid19).

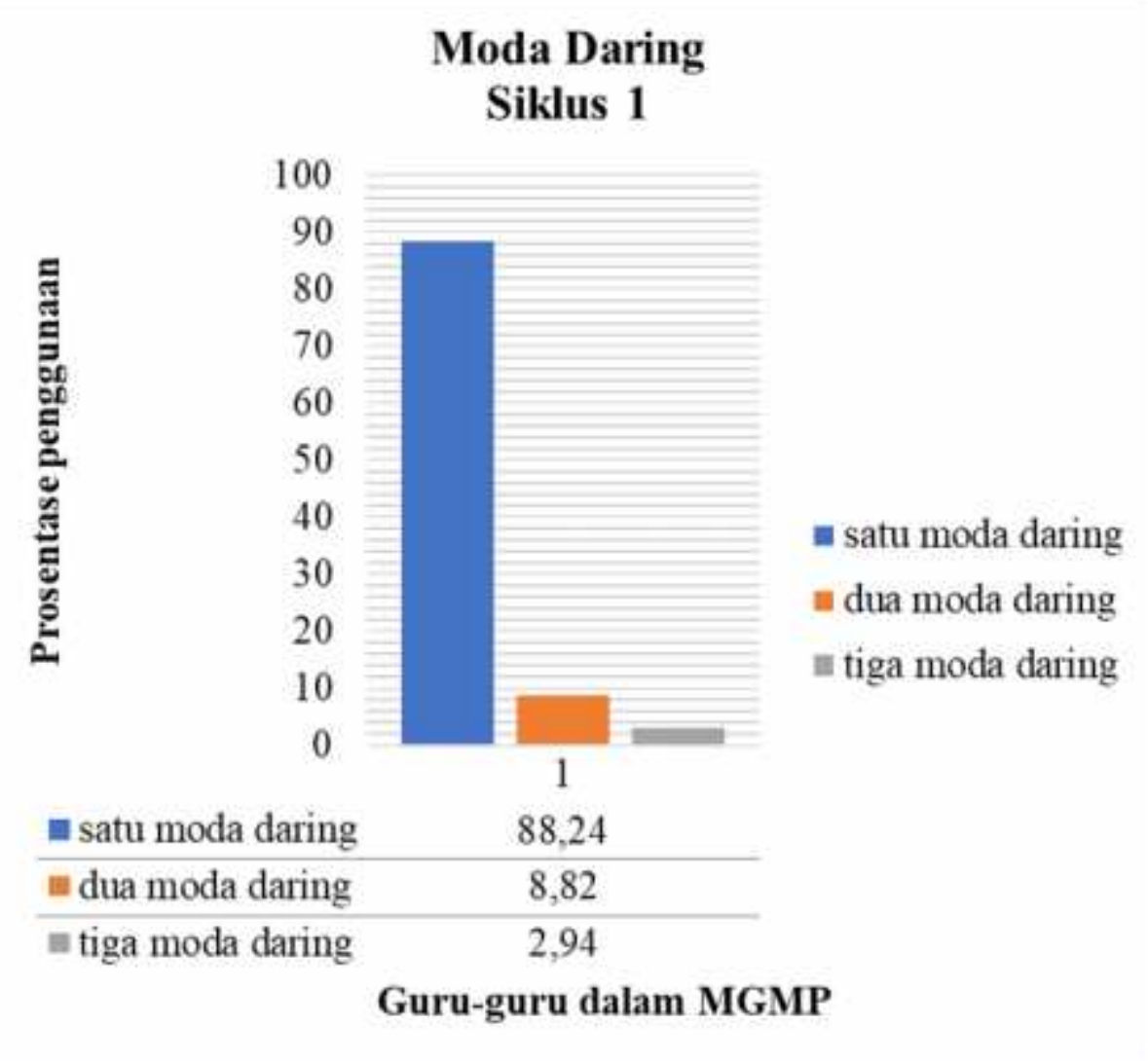

Gambar 2 : Moda daring siklus 1 
Menurut data pada siklus $1 \mathrm{di}$ atas, pendekatan pembelajaran daring dominan dilaksanakan melalui WA $88,24 \%$, dua moda daring $8,82 \%$ dan yang tiga moda daring $2,94 \%$. Pelaksanaan penelitian Tindakan sekolah pada siklus 2 bertujuan untuk memperbaiki kekurangan atau kelemahan dari perencanaan dan pelaksanaan dengan harapan dapat tercapai indikator keberhasilan. Adapun data yang diperoleh pada siklus 2 Dari 46 responden moda daring lewat wa $15,22 \%$, wa, melajah.id $39,13 \%$, google classroom, melajah.id $8,70 \%$, google form, melajah.id $4,35 \%$, quiper shool, google form $2,17 \%$, wa, google classroom 2,17\%, zoom, wa 4,35\%. Sedangkan guru yang menggunakan moda daring melajah.id, wa, google classroom 6,52\%, google form, google classroom, melajah.id $2,17 \%$ dan wa, google form, melajah.id $13,04 \%$. Sedangkan guru yang menggunakan empat moda daring dalam pembelajaran dengan wa, google form, google classroom, melajah.id 2,17\%.

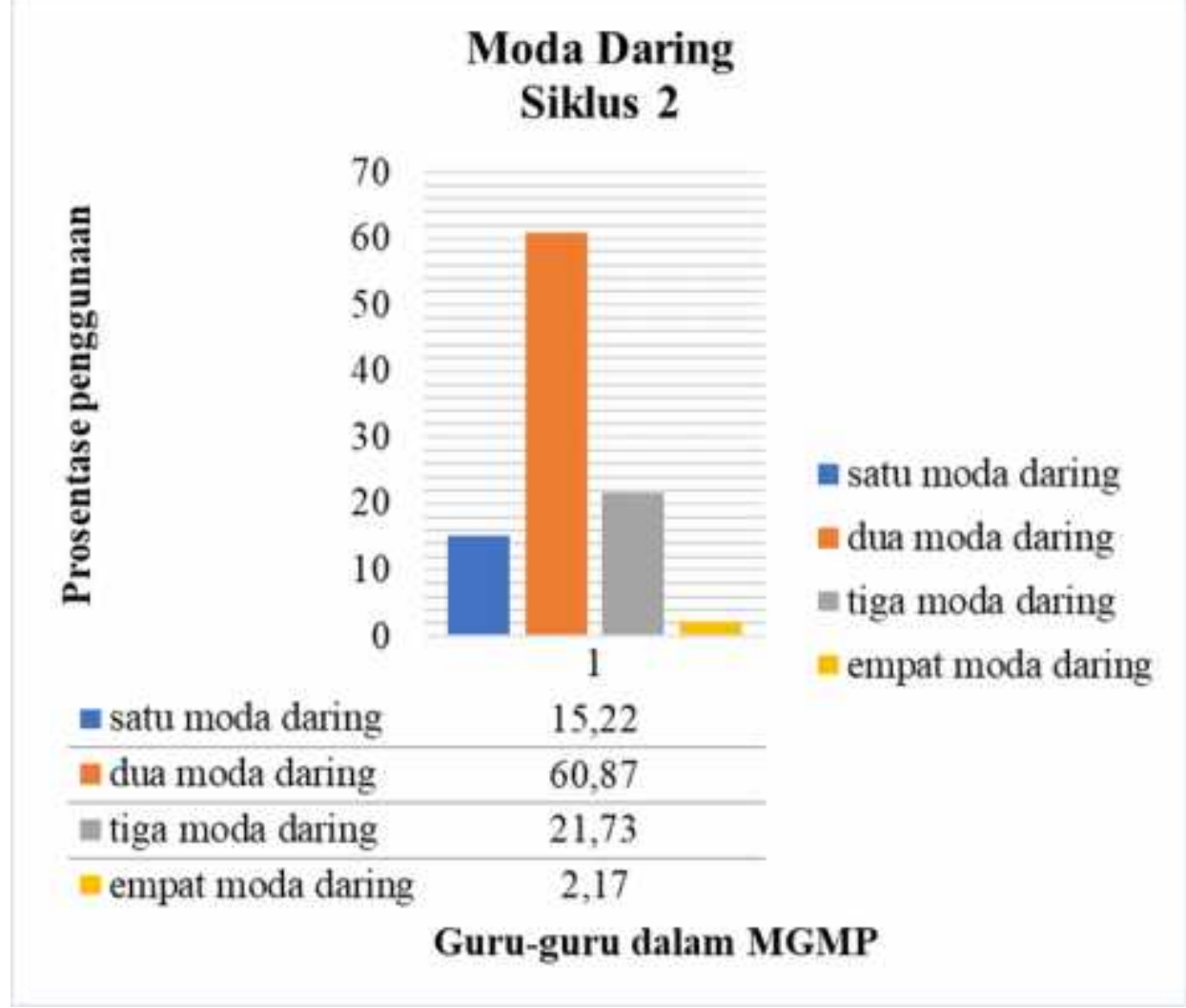

Gambar 3. Moda daring siklus 2

Dari data di atas guru yang menggunakan moda daring lewat wa tujuh orang $(15,22 \%)$, yang menggunakan dua moda daring 28 orang $(60,87 \%)$, yang menggunakan tiga moda daring 10 orang $(21,73 \%)$ serta guru dengan empat moda daring satu orang $(2,17 \%)$. 


\section{b. PEMBAHASAN}

Bertitik tolak pada kegiatan awal siklus, masih terdapat 3,39\% belum menggunakan pendekatan pembeljaran daring, dan masih tertumpu pada penggunaan satu moda daring. Memberikan gambaran rendahnya kemampuan guru-guru di SMPN 1 Banjarangkan dalam melaksanakan pendekatan pembelajaran daring. Beberapa hal penyebab masih rendahnya dalam pendekatan pembelajaran daring diantaranya kurangnya keberanian untuk bertanya, masih kurang pedamping atau pembimbing di bidang IT dalam pendekatan daring. Standar Kelulusan TIK SMP mengisyaratkan pentingnya memahami fungsi dan proses kerja berbagai peralatan TIK, memahami prinsip dasar internet/intranet dan menggunakannya untuk memperoleh informasi, berkomunikasi dan bertukar informasi (Kusumah Wijaya, 2018:46).

Usaha dan kerja keras peneliti dilakukan pada siklus pertama data yang diperoleh sebesar $8,82 \%$ dengan dua moda daring, masih minim penggunaan dua moda atau lebih, dan masih lebih kecil dari indikator keberhasilan yang ditetapkan. Hal ini disebabkan masih ada guru yang enggan atau malu bertanya, pembimbngan dilakukan sebatas hanya sesama anggota MGMP. Hal yang lain belum adanya tim khusus secara berjenjang dalam memberikan bimbingan terhadap guru-guru dalam wadah MGMP. Guru-guru dalam proses pedampingan masih tertumpu pada jadwal yang ditetapkan. Dalam MGMP akan didapatkan proses training atau pelatihan yang bersifat learning by doing dipandu oleh si pelatih dan ada praktek apa yang diajarkan dengan tujuan untuk mengembangkan pengetahuan, pemahaman dan ketrampilan para target/sasaran, hasilnya bisa segera terlihat (Sugianto, 2019) dalam Kiat Sukses Publikasi Ilmiah Guru (A. Sugen Thomas, 2020: 164).

Pada siklus dua, pendekatan pembelajaran daring mengalami peningkatan mencapai $60,87 \%$ dengan dua moda daring, 21,73 dengan tiga moda daring bahkan sudah ada guru yang menggunakan sampai empat moda daring sebesar 2,17\%. Hal ini disebabkan kemauan kuat peneliti, semangat tidak mengenal lelah selalu terpatri uuntuk melakukan inovasi pendekatan pembelajaran daring. Langkah-langkah konkrit peneliti lakukan melalui jadwal dengan pembimbing atau pedamping khusus yang medampingi guru-guru dalam wadah MGMP. Pembimbingan dilakukan secara berjenjang mulai dari anggota masing-masing MGMP, antar anggota MGMP yang berbeda, anggota MGMP dengan tim IT dan pembimbingan pun dilakukan dengan narasumber atau instruktur. Kepercayaan guru-guru bertambah, kepercayaan diri muncul baik bertanya, berdiskusi maupun dalam belajar teknologi. Hal ini dibuktikan guru yang sama sekali belum pernah mencoba dengan alat-alat teknologi seperti laptop atau notebook, terlihat keinginan kuat untuk mencoba berlatih dengan sungguh-sungguh. Proses pembimbingan tidak terpaku pada jadwal yang ditetapkan, melainkan diluar jadwal tatap muka MGMP pembimbingan dilakukan dengan sungguh-sungguh, bahkan pembimbingan dilakukan disamping di ruang guru, juga di lab. komputer juga di perpustakaan bahkan di alam terbuka agar kegiatan pembimbingan tidak kaku. Sebuah era dimana kaum kolonial harus banyak belajar dari kaum milineal, banyak mendengar sedikit 
bicara, memberikan keteladanan dalam menyiapkan diri menjadi guru atau dosen yang mampu menjadi pemain di era revolusi industry 4.0. (Kusumah Wijaya, 2020:82). Karena telah mencapai indikator keberhasilan yang ditetapkan maka penelitian dapat dikatakan telah berhasil sehingga penelitian dapat dihentikan. Dari kemampuan literasi digital yang dmilki guru-guru memberikan dampak terhadap literasi digital pada siswa, siswa memiliki kemampuan yang meningkat pula dalam penguasaan teknologi. Siswa semakin lancar dan terpacu lagi dalam belajar IT. Pembelajaran tidak membosankan, lebih menarik dan tertantang karena siswa dengan bimbingan guru terus berlatih dalam menguasai pendekatan pembelajarn daring. Dampak lainnya pembelajaran lebih terarah, terpadu dan terjalin komunikasi dan proses bimbingan antara guru dan siswa, antara siswa dengan siswa, antara guru dengan guru, juga antar guru dengan narasumber, jadi komunikasinya multi arah. Penerapan literasi digital melalui pemberdayaan MGMP berbasis kolaborasi atau pembimbingan timbul suasana kebersamaan, keberanian untuk bertanya, saling berbagi dan menjadi landasan kuat dalam membentuk team work dalam upaya menigkatkan kualitas diri guru dan kualitas pembelajaran. Dampak pada satuan Pendidikan, adanya budaya mutu berbasis digital dalam penerapan pembelajaran. Karena sekolah telah memiliki LMS Melajah.id yang meruapakan sistem desain pembelajaran sesuai dengan perkembangan pendidikan berbasis global sesuai dengan tuntutan pembelajaran abad-21. Guru dan siswa semakin melek teknologi, bukan sebaliknya karena sekolah yang berkualitas dapat dilihat dari kesiapan dan penguasaan literasi digital yang mampu dimplemtesaikan untuk menumbuhkan jiwa teknokrat pada warga sekolah. Absen kehadiran guru dalam proses pembelajaran daring dari rumah, awalnya menggunakan daftar hadir secara manual, yang sangat rumit, lama menghitungnya karena menggunakan turus secara manual, telah berubah dengan menggunakan google form yang sudah dapat direkap secara cepat kehadiran guru dalam proses pembelajaran. Guru-guru mampu merekam suara lewat voice untuk menyampaikan pengumuman-pengumuman penting kepada peserta didik. Sehingga komunikasi lewat audio pun dapatt dilakukan oleh para guru, jika pembelajaran terhambat lewat visual.

\section{KESIMPULAN}

Dari uraian di atas dapat dismpulkan bahwa peningkatan penguasaan moda daring guru-guru di SMPN 1 Banjarangkan dapat dilakukan melalui pemberdayaan MGMP sekolah berbasis kolaborasi. Hal ini dapat ditujukkan dengan data pada awal siklus penggunaan satu moda daring mencapai $88,14 \%$, melalui dua moda daring $8,47 \%$ dan 3,39 tanpa moda daring. Pada siklus 1 pendekatan moda daring melalui satu moda daring 88, 24\%, dua moda daring 8,82\% dan tiga moda daring 2,94\%. Sedangkan pada siklus 2 penggunaan satu moda daring $15,22 \%$, dua moda daring $60,87 \%$, tiga moda daring 21,73\%, empat moda daring 2,17\%. Dari uraian di atas, terjadi peningkatan yang signifikan penggunaan moda daring dari pra siklus kesiklus 1 dengan dua moda daring 0,35\%, penggunaan tiga moda daring 2,94\% belum terdapat guru yang menggunakan empat moda daring dalam pembelajaran. 
Sedangkan dari siklus 1 ke siklus 2 penggunaan dua moda daring mengalami peningkatan $52,05 \%$, penggunaan tiga moda daring meningkat $18,79 \%$ dan penggunaan empat moda daring meningkat $2,17 \%$. Dengan peningkatan penggunaan dua moda daring 52,05\% dan 18,79\% untuk penggunaan tiga moda daring maka telah memenuhi indikator keberhasilan penelitian yang menargetkan minimal 50\% pengunaan dua moda daring dalam pmebelajaran dan minimal 20\% guru-guru telah menggunakan tiga moda daring. MGMP sekolah sebagai organisasi pada satuan Pendidikan memberikan manfaat dalam peningkatan kualitas guru dan penanaman karakter yang berpengaruh pula pada peningkatan kualitas pembelajaran. Keberadaan organisasi MGMP sekolah dalam rangka pengembangan literasi digital berbasis kolaborasi memberikan dampak pada budaya mutu sekolah. Diharapkan guru-guru di SMPN 1 Banjarangkan dapat terus meningkatkan kemampuan dalam penguasaan literasi digital dalam pendekatan moda daring khususnya pada masa pandemi yang berpengaruh pada kualitas pembelajaran. Satuan Pendidikan melalui Kepala Sekolah dapat menjadikan pengembangan literasi sekolah melalui pendekatan moda daring berbasis kolaborasi melalui pemberdayaan MGMP sekolah terus dilanjutkan, ditingkatkan dan dikembangkan bukan saja pada guru-guru juga mencakup seluruh warga sekolah.

\section{DAFTAR PUSTAKA}

A. Sogen, Thomas 2020. Kiat Sukses Publikasi Ilmiah Guru, Sukoharjo: CV Oase Pustaka.

Direktorat Jenderal Guru dan Tenaga Kependidikan Kementerian Pendidikan dan Kebudayaan, 2020. Panduan Pembelajaran Jarak Jauh : Jakarta

Doni Koesoema A., Pendidikan Karakter Berbasis Kelas Menumbuhkan Karakter dalam Pembelajaran, Penerbit PT Kanisius Yogyakarta, 2018.

Kementerian Pendidikan Dan Kebudayaan, Surat Edaran Nomor 15 Tahun 2020 Tentang Pedoman Penyelenggaraan Belajar Dari Rumah Dalam Masa Darurat Penyebaran Coron Virus Disease (Covid-19), Jakarta 18 Mei 2020.

Kusumah Wijayah 2018. Blogger Ternama (Jadilah Blogger Terkenal di Era Digital dengan Ketrampilan Menulis), Jakarta Barat. CV. Campustaka.

Kusumah Wijayah, 2020. Catatan Harian Seorang Guru Blogger, Semarang. Lembaga Pendidikan Sukarno Pressindo.

Landep Widia Asmara I Ketut, 2017. Cara Mudah Menyusun Laporan Hasil Penelitian Tindakan Kelas (PTK) Pendekatan Empirik, Bali:Pustaka Ekspresi.

Peraturan Menteri Pendidikan Nasional Nomor 35 Tahun 2010 Tanggal 1 Desember 2010 Tentang Petunjuk Teknis Pelaksanaan Jabatan Fungsional Guru Dan Angka Kreditnya. 